\title{
Molecular detection of Marteilia sydneyi, pathogen of Sydney rock oysters
}

\author{
Sarah N. Kleeman ${ }^{1, *}$, Robert D. Adlard $^{2}$ \\ ${ }^{1}$ Department of Parasitology, University of Queensland, Brisbane, Queensland 4072, Australia \\ ${ }^{2}$ Protozoa Section, Queensland Museum, PO Box 3300, South Brisbane, Queensland 4101, Australia
}

\begin{abstract}
The life cycle of Marteilia sydneyi, the aetiological agent of QX disease in the Sydney rock oyster Saccostrea commercialis, is not known. We have developed and optimised 2 diagnostic assays, the polymerase chain reaction (PCR) and in situ hybridisation, for use in investigating the role of possible alternative hosts in the life cycle of this pathogen. PCR primers, designed within the ITS1 rDNA of $M$. sydneyi, amplified a 195 bp fragment. Sensitivity of the PCR assay was assessed using DNA extracted from known numbers of sporonts purified from infected oyster digestive gland. DNA equivalent to 0.01 sporonts was detectable following agarose gel electrophoresis. The potential inhibitory effect of the presence of host DNA on the PCR assay was tested by the addition of oyster genomic DNA during amplification. Concentrations of host DNA in excess of $50 \mathrm{ng}$ per $20 \mu \mathrm{l}$ reaction reduced the sensitivity of the test. Environmental validation of the PCR assay was demonstrated by the amplification of $M$. sydneyi DNA from $50 \mathrm{ng}$ of genomic DNA extracted from QX-infected oysters. A. DNA probe was constructed using the $M$. sydneyi unique primers and was able to detect $10 \mathrm{pg}$ of $M$. sydneyi PCR amplified DNA in dot-blot hybridisations. The probe hybridised with presporulating and sporulating $M$. sydneyi stages in paraffin sections of oyster digestive gland. No non-specific binding was observed. Hybridisation consistency and signal intensity decreased as sporonts matured. While the high sensitivity and specificity of the PCR test will allow rapid screening of large numbers of potential alternative hosts for the presence of parasite DNA, it does not actually identify infective stages. In situ hybridisation conducted on paraffin sections will determine the location of the parasite within the host for morphological characterisation.
\end{abstract}

KEY WORDS: Marteilia sydneyi PCR primers - DNA probe In situ hybridisation - Saccostrea commercialis - rDNA gene sequence

\section{INTRODUCTION}

Marteilia sydneyi, the aetiological agent of QX disease, is recognised as the most pathogenic parasite of the Sydney rock oyster Saccostrea commercialis in culture on the east coast of Australia, where stock mortalities in excess of $90 \%$ have been recorded. Prior to 1994, QX infections were recorded from the Great Sandy Strait $\left(25^{\circ} 30^{\prime} \mathrm{S}\right)$ south to the Macleay River $\left(31^{\circ} \mathrm{S}\right)$, after which time its range had extended further south to include the Georges River estuary $\left(34^{\circ} \mathrm{S}\right)$ (Adlard \& Ernst 1995). Although current management strategies exist to keep stock losses within manageable

\footnotetext{
•E-mail:s.kleeman@mailbox.uq.edu.au
}

limits and prevent further geographic spread of the disease, potential control is hindered by the incomplete understanding of the life cycle of this pathogen. Development and ultrastructure of presporulating and sporulating stages in the oyster host are described (Perkins \& Wolf 1976); however, the stage infective to the oyster and its origin are unknown. Failure to infect oysters experimentally with mature spores (Lester 1986) and recent evidence which suggests a limited period of viability of spores in seawater (Wesche et al. 1999) have implicated the involvement of an intermediate host.

Traditionally, detection of $\mathrm{QX}$ in oyster tissue involved microscopical examination of histological sections. Wet smears of hepatopancreas, in which refractile bodies in sporonts are characteristic of infection, 
provided a simple and rapid diagnosis when sporonts were present. Current diagnosis is based on the examination of Hemacolor (Merck)-stained imprints of hepatopancreas which enable rapid detection of all developmental stages, including presporulating stages, undetectable in wet preps, within a few days of initial infection. These techniques cannot identify unambiguously stages of Marteilia sydneyi of unknown morphology that may occur in alternate hosts, highlighting the need for an appropriate diagnostic tool. An indirect fluorescent antibody test (IFAT) was developed (Roubal \& Lester 1987) but was considered an unreliable guide to infection as it did not react to the contents of the spore (Roubal et al. 1989), the most likely stage to be present in an alternate host.

DNA techniques display levels of sensitivity and specificity, irrespective of life cycle stage, required for such a test. PCR and in situ hybridisation assays have proven to be useful tools for discase detection in aquatic animals (Adlard \& Lester 1995, Chang et al. 1996, Durand et al. 1996, Lo et al. 1997, Wang et al. 1997 ) and are considered suitable tools for life cycle studies (Fong et al. 1993, Stokes \& Burreson 1995, Stokes et al. 1995). Polymerase chain reaction (PCR) primers developed by Anderson et al. (1995) were found to be specific to Marteilia sydneyi. However, their location in the rDNA gene cluster was not confirmed and subsequent analysis revealed low levels of sensitivity in PCR (Adlard unpubl. data)

In this paper we describe the development and optimisation of 2 diagnostic assays based on PCR and in situ hybridisation, utilising PCR primers that amplify specific DNA regions within the ribosomal DNA cluster of Marteilia sydneyi, which can then be applied to investigate the role of possible alternate hosts in the life cycle of this important pathogen.

\section{METHODS}

Specimen preparation. Oysters were tested for the presence of Marteilia sydneyi by microscopical examination of Hemacolor (Merck)-stained imprints of oyster digestive gland. Infected oysters were classified as having: (1) presporulation stage of infection if plasmodia and secondary cells were identified in imprints; and (2) progressive stage of infection if all developmental stages (plasmodia, secondary cells, immature and mature sporonts) were present. Sporonts of $M$. sydneyi were purified from homogenised digestive gland of infected oysters by centrifugation on discontinuous sucrose and Percoll gradients as described by Mialhe et al. (1985). Tissue samples of uninfected oysters, oysters with presporulation stages of QX and oysters with progressive stages of infection were fixed for 6 to $24 \mathrm{~h}$ in $10 \%$ buffered formalin, dehydrated in alcohol and embedded in paraffin. Histological sections $(6 \mu \mathrm{m})$ were stained in haematoxylin and eosin (H\&E) to confirm presence or absence of $M$. sydneyi in adjacent sections.

DNA extraction and purification. Genomic DNA was extracted from purified sporonts, Marteilia sydneyi infected Saccostrea commercialis digestive gland and sperm of uninfected oysters by digestion in a solution of extraction buffer $(100 \mathrm{mM}$ Tris, pH 8.0, $100 \mathrm{mM}$ EDTA, pH 8.0, $100 \mathrm{mM} \mathrm{NaCl}$, $10 \%$ SDS and Proteinase $\mathrm{K}\left(20 \mathrm{mg} \mathrm{m}^{-1}\right)$ at $56^{\circ} \mathrm{C}$ for 4 to $24 \mathrm{~h}$. Remaining proteins and polysaccharides were removed by phenol/ chloroform/isoamyl alcohol extraction and nucleic acids recovered by ethanol precipitation (see Sambrook et al. 1989). DNA concentration and purity were estimated by measuring the 260/280 optical density ratio of a solution following RNase treatment $(0.2 \mu \mathrm{g}$ RNase per $\mu \mathrm{l}$ of genomic DNÁA.

Primer synthesis. A reverse primer, based on the putative first internal transcribed spacer (ITS1) sequence given by Anderson et al. (1995), was designed and designated PRO2. It was synthesised from the reverse complement of PRO1 (Anderson et al. 1995) such that PRO2 $=5$ '-TCA AGG GAC ATC CAA CGG TC-3'. This primer was then used in a PCR amplification with a forward primer designated RA2 (5'-GTC CCT GCC CTT TGT ACA CA-3') with annealing site in a conserved region of the small subunit (SSU), 180 nucleotide bases upstream of the boundary between the SSU and ITS1.

This PCR produced an amplified fragment of $430 \mathrm{bp}$ when compared on an agarose gel with a molecular weight standard (100 bp ladder, GibcoBRL). The nucleotide sequence was determined for this fragment using the same primers as sequencing primers, then compared for homology with known SSU sequences (Cryptocaryon irritans, and compared using Blast routine on GenBank) to confirm its location in the rDNA cluster. To increase the species specificity for hybridisation of a PCR-generated probe, a second forward primer designated LEG1, 5'-CGA TCT GTG TAG TCG GAT TCC GA-3', was designed from this sequence within the original fragment, but positioned 48 nucleotide bases downstream of the SSU/ITS1 boundary.

PCR. PCR was performed under the following reaction parameters unless otherwise stated, expressed as final concentrations: $\mathrm{MgCl}_{2} 2 \mathrm{mM}$; buffer $67 \mathrm{mM}$ Tris-

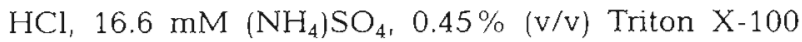
dNTP's $200 \mathrm{mM}$; primers 10 pmol each; Taq polymerase (Boehringer, Mannheim) $3 \mathrm{U}$; DNA $50 \mathrm{ng}$, ultrapure water to $50 \mu \mathrm{l}$ total. Thermal cycling parameters were as follows: denaturation at $95^{\circ} \mathrm{C}$ for $60 \mathrm{~s}$; primer annealing at $55^{\circ} \mathrm{C}$ for $30 \mathrm{~s}$; chain extension at $72^{\circ} \mathrm{C}$ for $60 \mathrm{~s}$, repeated for 30 cycles with a final cycle incorpo- 
rating a 7 min extension. Electrophoresis of amplified products was conducted through submarine agarose gels $(1.2 \%[\mathrm{w} / \mathrm{v}]$ agarose, $1.2 \mu \mathrm{l}$ ethidium bromide $\left[10 \mathrm{mg} \mathrm{ml} \mathrm{l}^{-1} \mathrm{w} / \mathrm{v}\right]$ in $20 \mathrm{ml}$ total, for $30 \mathrm{~min}$ at $100 \mathrm{~V}$ per $20 \mathrm{~mA}$ ) and examined and photographed under ultraviolet light. A molecular weight standard (100 bp ladder, Gibco BRL) was used to estimate the size of products

DNA sequencing. Amplified products were purified using Qiaquick PCR purification spin columns (Qiagen Inc). The concentration of the purified product was assessed by comparison on an agarose gel with DNA of a known mass (Mass ladder, GibcoBRL), then an estimated $50 \mathrm{ng}$ of purified PCR product used in a cycle sequencing reaction employing dye-nucleotide terminators (ABI, Prism Ready Reaction Terminator Kit). Sequencing reaction products were purified with phenol/chloroform and sequenced on an ABI 373A automated sequencer. Sequences were manipulated and analysed using the computer software ESEE (Cabot \& Beckenbach 1989).

PCR sensitivity. Purified Marteilia sydneyi sporonts were counted using a Nebauer haemocytometer, diluted to a working concentration of $1 \times 10^{6}$ sporonts and DNA extracted following the previously described method. Serial dilutions from 100 to 0.001 sporont DNA equivalents ( $63.8 \mathrm{pg}$ to $0.638 \mathrm{fg}$ ) were used as template in $20 \mu \mathrm{lPCR}$ reactions. To determine if the sensitivity of the PCR reaction was compromised by the presence of host tissue, 50,100, 200 and $400 \mathrm{ng}$ of genomic DNA extracted from uninfected oyster sperm was added to $20 \mu \mathrm{l}$ PCR reactions containing serial dilutions of 100 to 0.01 sporont DNA equivalents. Environmental validation of the $\mathrm{PCR}$ reaction was carried out on $50 \mathrm{ng}$ of genomic DNA extracted from wild oysters assessed to have: no parasite presence; low (<1 parasite per $200 \times$ field of view); medium ( 1 to 25 parasites per $200 \times$ field of view); and high ( $>25$ parasites per $200 \times$ field of view) intensities of $M$. sydneyi infection, as determined in imprints. Results were assessed on ethidium bromide-stained agarose gels.

Labelling of DNA probe. The DNA probe was synthesised by incorporation of dioxygenin-11-dUTP during PCR using the Marteilia sydneyi specific primers PRO2 and LEG1, 40 to $60 \mathrm{ng}$ of genomic DNA extracted from purified sporonts and the PCR DIG Probe Synthesis Kit (Boehringer, Mannheim) according to the protocol suggested by the manufacturer. Incorporation of digoxigenin was indicated by an increase in molecular mass as analysed on ethidium bromidestained agarose gels and the labeled PCR product purified using the High Pure PCR Product Purification Kit (Boehringer, Mannheim). Probe concentration was estimated by side-by-side comparison of diluted series of the probe and DIG-labelled control (Boehringer,
Mannheim) in a spot test on nylon membranes according to the methodology in the application manual.

DIG-labelled DNA probe sensitivity. Sensitivity of the probe was determined in dot-blot hybridisations. Serial dilutions from $10 \mathrm{ng}$ to $1 \mathrm{pg}$ of Marteilia sydneyi PCR cloned DNA were heat-denatured and spotted onto nylon membranes then fixed by UV crosslinking for $3 \mathrm{~min}$. Membranes were prehybridised in $3 \times \mathrm{SSC}$ $(20 \times \mathrm{SSC}=3 \mathrm{M} \mathrm{NaCl} ; 0.3 \mathrm{M} \mathrm{Na}$-citrate, pH 7.0), $50 \%$ formamide, $1 \times$ Denhardt's solution and $0.5 \mathrm{mg} \mathrm{ml}^{-1}$ heat denatured herring sperm DNA at $37^{\circ} \mathrm{C}$ for $2 \mathrm{~h}$. The prehybridisation buffer solution was replaced with hybridisation buffer $(3 \times \mathrm{SSC}, 50 \%$ formamide, $1 \times$ Denhardt's solution and $0.5 \mathrm{mg} \mathrm{ml}^{-1}$ heat denatured herring sperm DNA and $5 \%$ Dextran sulfate) containing $50 \mathrm{ng} \mathrm{ml}^{-1}$ DIG-labelled DNA probe and incubated overnight at $42^{\circ} \mathrm{C}$. Removal of unhybridised probe was achieved by two $5 \mathrm{~min}$ washes in $2 \times \mathrm{SSC}$ at room temperature and two $15 \mathrm{~min}$ washes at $42^{\circ} \mathrm{C}$ with $0.1 \times$ $\mathrm{SSC}$. Following equilibration in maleic acid buffer (100 mM maleic acid, $150 \mathrm{mM} \mathrm{NaCl}$, pH 7.5), membranes were blocked for $30 \mathrm{~min}$ at room temperature in blocking buffer (maleic acid buffer plus $1 \%$ blocking reagent; Boehringer, Mannheim). Membranes were incubated at room temperature for $30 \mathrm{~min}$ with antidioxygenin-alkaline phosphatase antibody (Boehringer, Mannheim) diluted 1:5000 in blocking buffer followed by removal of unbound antibody with two $15 \mathrm{~min}$ washes in washing buffer (maleic acid buffer $+0.3 \%$ Tween 20). After equilibration in detection buffer (100 mM Tris- $\mathrm{HCl}, 100 \mathrm{mM} \mathrm{NaCl}, 50 \mathrm{mM} \mathrm{MgCl}$, $\mathrm{pH}$ 9.5) the membrane was incubated at room temperature in the dark for 4 to $5 \mathrm{~h}$ in 5-bromo-4-chloro-3indolyl phosphate/nitro blue tetrazolium (NBT/BCIP) diluted in detection buffer. The reaction was stopped with a TE buffer wash

In situ hybridisation. Tissue sections from oysters previously diagnosed in imprints to have no infection, presporulation stages only and all developmental stages of QX were cut $6 \mu \mathrm{m}$ thick and placed on silanized slides (PROSCITEC) and baked for $45 \mathrm{~min}$ at $60^{\circ} \mathrm{C}$. Sections were deparaffinized, rehydrated in an ethanol series, and treated with $0.2 \mathrm{M} \mathrm{HCl}$ for $10 \mathrm{~min}$. Sections were permeabilized with $10 \mu \mathrm{g} \mathrm{ml}^{-1}$ Proteinase $\mathrm{K}$ in TNE (50 mM Tris- $\mathrm{HCl}, 10 \mathrm{mM} \mathrm{NaCl}, 1 \mathrm{mM}$ EDTA. $2 \mathrm{H}_{2} \mathrm{O}$, $\mathrm{pH} \mathrm{7.4)}$ for $30 \mathrm{~min}$ at $37^{\circ} \mathrm{C}$ in a humid chamber. Proteolysis was inactivated by two $1 \mathrm{~min}$ washes in PBS followed by equilibration in $2 \times \mathrm{SSC}$. Samples were prehybridised in $500 \mathrm{ml}$ prehybridisation buffer in a humid chamber for $60 \mathrm{~min}$ at $37^{\circ} \mathrm{C}$. The prehybridisation buffer solution was replaced with $100 \mathrm{ml}$ of hybridisation buffer containing 5 to $10 \mathrm{ng}$ per $100 \mathrm{ml}$ heat-denatured DIGlabelled probe. Sections were covered with plastic coverslips and placed on a heating block at 85 to $95^{\circ} \mathrm{C}$ for 5 min to denature the target DNA then immediately 
cooled on ice for 5 min and allowed to hybridise overnight in a humid chamber at $42^{\circ} \mathrm{C}$. Post hybridisation washes including $2 \times \mathrm{SSC}$ at room temperature, twice for $5 \mathrm{~min}$, and $0.1 \times \mathrm{SSC}$ at $42^{\circ} \mathrm{C}$, once tor $10 \mathrm{~min}$ were carried out, followed by equilibration in maleic acid buffer. DIG-labelled probe detection included blocking sections with $500 \mu \mathrm{l}$ blocking buffer at $37^{\circ} \mathrm{C}$ for $15 \mathrm{~min}$ followed by incubation for $1 \mathrm{~h}$ at $37^{\circ} \mathrm{C}$ with $500 \mu \mathrm{l}$ of dilute antidioxygenin-alkaline phosphatase conjugate 1 :1000 in blocking buffer). Unbound antibody was removed with two 5 min washes in washing buffer and one $5 \mathrm{~min}$ wash in detection buffer. NBT/BCIP was diluted in detection buffer plus $1 \%$ polyvinyl alcohol and $1 \mathrm{mM}$ levamisole and $100 \mu \mathrm{l}$ of the colour solution added to the tissue and incubated at room temperature in the dark for 4 to $5 \mathrm{~h}$. The reaction was stopped with a TE buffer wash. Slides were washed in $\mathrm{dd}_{2} \mathrm{O}$ and stained for 1 min in Bismark brown $Y$ followed by ethanol dehydration and mounted in DPX via toluene. Hybridisation conditions were optimised by varying the concentrations of Proteinase $K$ and the DIG-labelled DNA probe. Negative controls included samples without the digoxigenin-labelled probe in the hybridisation mixture.

\section{RESULTS}

Extended sequence data of the putative ITS1 sequence given by Anderson et al. (1995) were aligned with known sequences (Cryptocaryon irritans, see Diggles \& Adlard 1995), and confirmed their position in the rDNA gene cluster (Fig. 1). The forward primer LEG1 and the reverse primer PRO2 provided the basis for a specific PCR amplification of a 195 bp fragment within the ITS1 sequence of Marteilia sydneyi (Fig. 1).

\section{PCR sensitivity}

The PCR assay was found to be sensitive enough to repeatedly amplify a DNA concentration equivalent to 0.01 sporonts (6.38 fg) (Fig. 2). Addition of $50 \mathrm{ng}$ of host DNA to the reaction did not compromise the sensitivity of the test; however, the intensity of the signal was reduced (Fig. 3A). Further reductions in signal intensity and inhibition of the PCR were found at host DNA concentrations greater than and equal to $100 \mathrm{ng}$. In the presence of 100 and $200 \mathrm{ng}$ of host DNA the PCR test was able to detect 1 and 100 sporont DNA equivalents, respectively (Fig. 3B,C). One hundred sporont DNA equivalents were not detectable in PCR after addition of $400 \mathrm{ng}$ of host DNA (Fig. 3D). Marteilia sydneyi infections in Saccostrea commercialis, ranging in intensity from low to high, were detectable in PCR. Uninfected oysters yielded no result (Fig. 4).

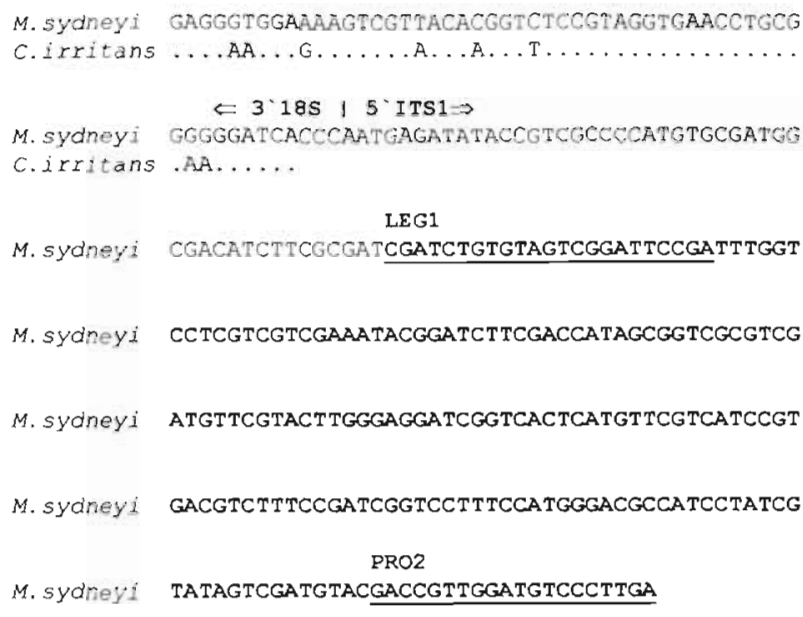

Fig. 1. Ribosomal DNA nucleotide sequence of the ITS1 and flanking $18 \mathrm{~S}$ region of Marteilia sydneyi isolated from Saccostrea commercialis (GenBank accession number: RankIt275614 AF159248). The sequence of the PCR primers LEG1 and PRO2 are underlined. The 195 bp DNA probe sequence is marked in bold. Alignment with Cryptocaryon irritans data for $18 \mathrm{~S}$ taken from Diggles \& Adlard (1995). Periods indicate homologous base

\section{DNA probe sensitivity}

Fifty ng ml-1 of the DNA probe detected consistently $10 \mathrm{pg}$ of PCR amplified Marteilia sydneyi DNA in dot blot hybridisations (Fig. 5).

\section{In situ hybridisation}

The DNA probe hybridised with presporulating and sporulating stages of Marteilia sydneyi in paraffin-em-

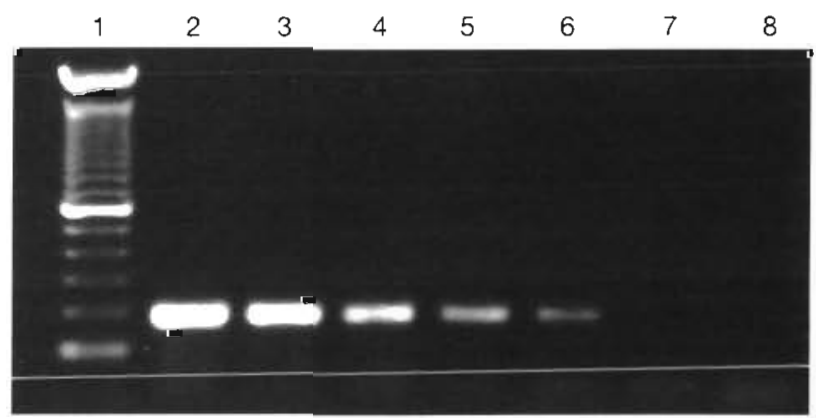

Fig. 2. Agarose gel electrophoresis assessment of the sensitivity of the primer pair LEG1./PRO2 in PCR on various concentrations of Marteilia sydneyi DNA extracted from sporonts purified from infected Saccostrea commercialis. Lane 1, 100 bp ladder; lane 2, 100 sporont DNA equivalents (63.8 pg); lane 3,10 sporont DNA equivalents $(6.38 \mathrm{pg})$; lane 4,1 sporont DNA equivalent $(0.638 \mathrm{pg})$; lane $5,0.1$ sporont DNA. equivalents $(63.8 \mathrm{fg})$; lane 6, 0.01 sporont DNA equivalents $(6.38 \mathrm{fg})$; lane 7, 0.001 sporont DNA equivalents $(0.638 \mathrm{fg})$; lane 8, no DNA control 

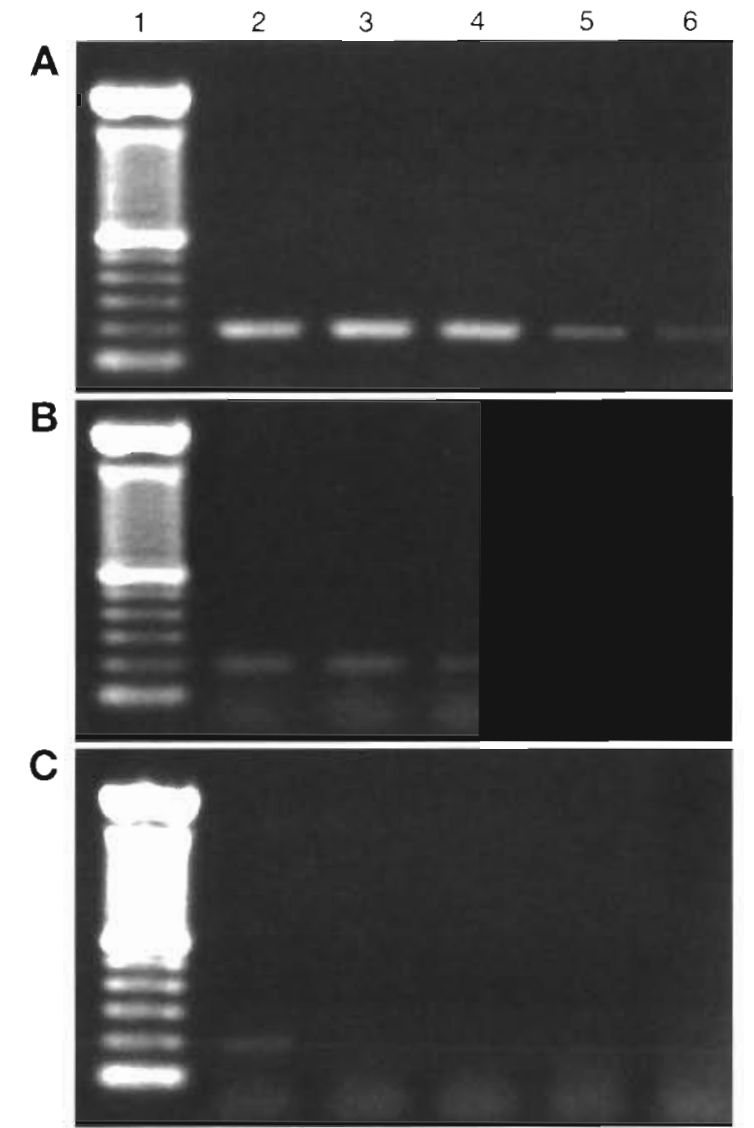

D

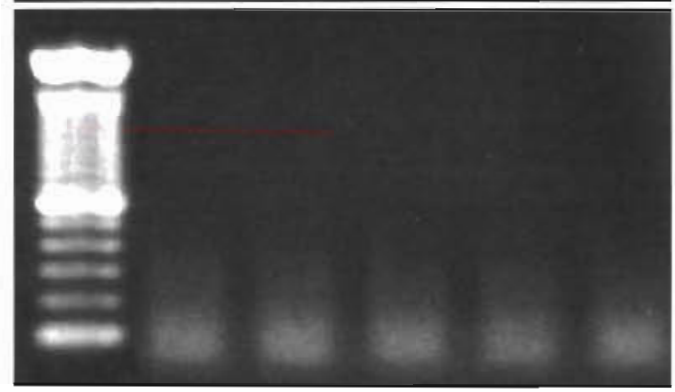

Fig. 3. Assessment of the sensitivity of the primer pair LEG1/PRO2 in PCR on various concentrations of Marteilia sydneyj DN. $\rightarrow$ extracted from purified sporonts in the presence of increasing concentrations of genomic DNA extracted from uninfected Saccostrea commercialis. Ethidium bromide staining of $M$. sydneyi amplification products in the presence of (A) $50 \mathrm{ng}$; (B) $100 \mathrm{ng}$; (C) $200 \mathrm{ng}$; (D) $400 \mathrm{ng}$ of $S$. commercialis genomic DNA. Lane 1, 100 bp ladder; lane 2, 100 sporont DNA equivalents $(63.8 \mathrm{pg})$; lane 3,10 sporont DNA equivalents $(6.38 \mathrm{pg})$; lane 4,1 sporont DNA equivalent $(0.638 \mathrm{pg})$; lane $5,0.1$ sporont DNA equivalents $(63.8 \mathrm{fg})$; lane $6,0.01 \mathrm{spo-}$ ront DNA equivalents $(6.38 \mathrm{fg})$

bedded tissue prepared from an oyster determined to have a progressive stage of infection, with negligible background hybridisation (Fig. 6A). Parasite identity and location were confirmed in the adjacent section after staining with $\mathrm{H} \& \mathrm{E}$ (Fig. 6B). Individual plasmodia and secondary cell stages in oyster tissue prepared

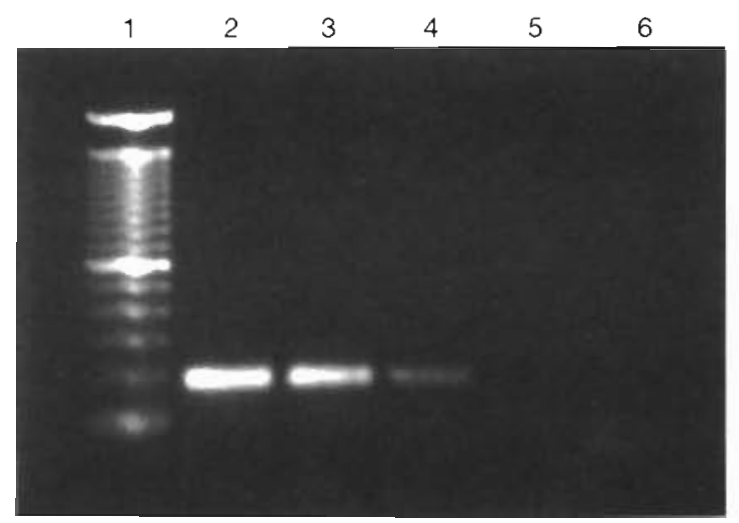

Fig. 4. Environmental validation of the PCR test on $\mathrm{QX}$ infected Saccostrea commercialis with various intensities of infection. Lane 1, 100 bp ladder; lane 2, high infection intensity; lane 3, medium infection intensity; lane 4, low infection intensity; lane 5, uninfected oyster; lane 6, no DNA control

from an individual with a presporulation stage of infection were easily located following probe detection (Fig. 6C), but were difficult to locate in histology at low power $(200 \times)$ (Fig. 6D). Negative control tissue samples known to be unparasitized showed no non-specific hybridisation to oyster tissue (Fig. 6E). No signal was detected in $M$. sydneyi-infected tissue where the dioxygenin-labelled probe was omitted (Fig. 6F)

Hybridisation consistency and signal intensity varied with different developmental stages of the parasite. Plasmodia and secondary cells showed strong positive results in repeated assays (Fig. $7 \mathrm{~A}$ ). Immature sporonts exhibited consistent strong hybridisation signals localised within the spores (Fig. 7B). As the sporont matured the signal decreased progressively and hybridisation was detected inconsistently in very mature stages. Hybridisation was concentrated in the innermost and intermediate sporoplasms in mature spores with some reactivity in the spore wall (Fig. 7C). No signal was observed in the refringent granules (Fig. 7B,C). Mature spores in sporonts shed into the lumen of the digestive tubules hybridised strongly and consistently (Fig. 8A). The corresponding region in adjacent sections in histology confirmed maturity of shed spores

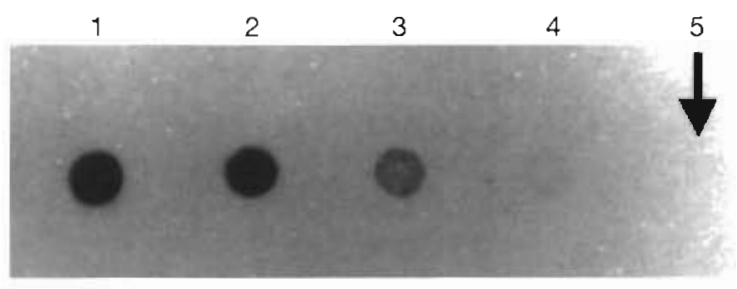

Fig. 5. Sensitivity of the DIG-labelled DNA probe in dot blot hybridisation. From left to right each dot contains: (1) $10 \mathrm{ng}$; (2) $1 \mathrm{ng} ;$ (3) $100 \mathrm{pg}_{\text {; }}$ (4) $10 \mathrm{pg}_{\text {; }}$ (5) $1 \mathrm{pg}$ of PCR-amplified Marteilia sydneyi SSU rDNA 


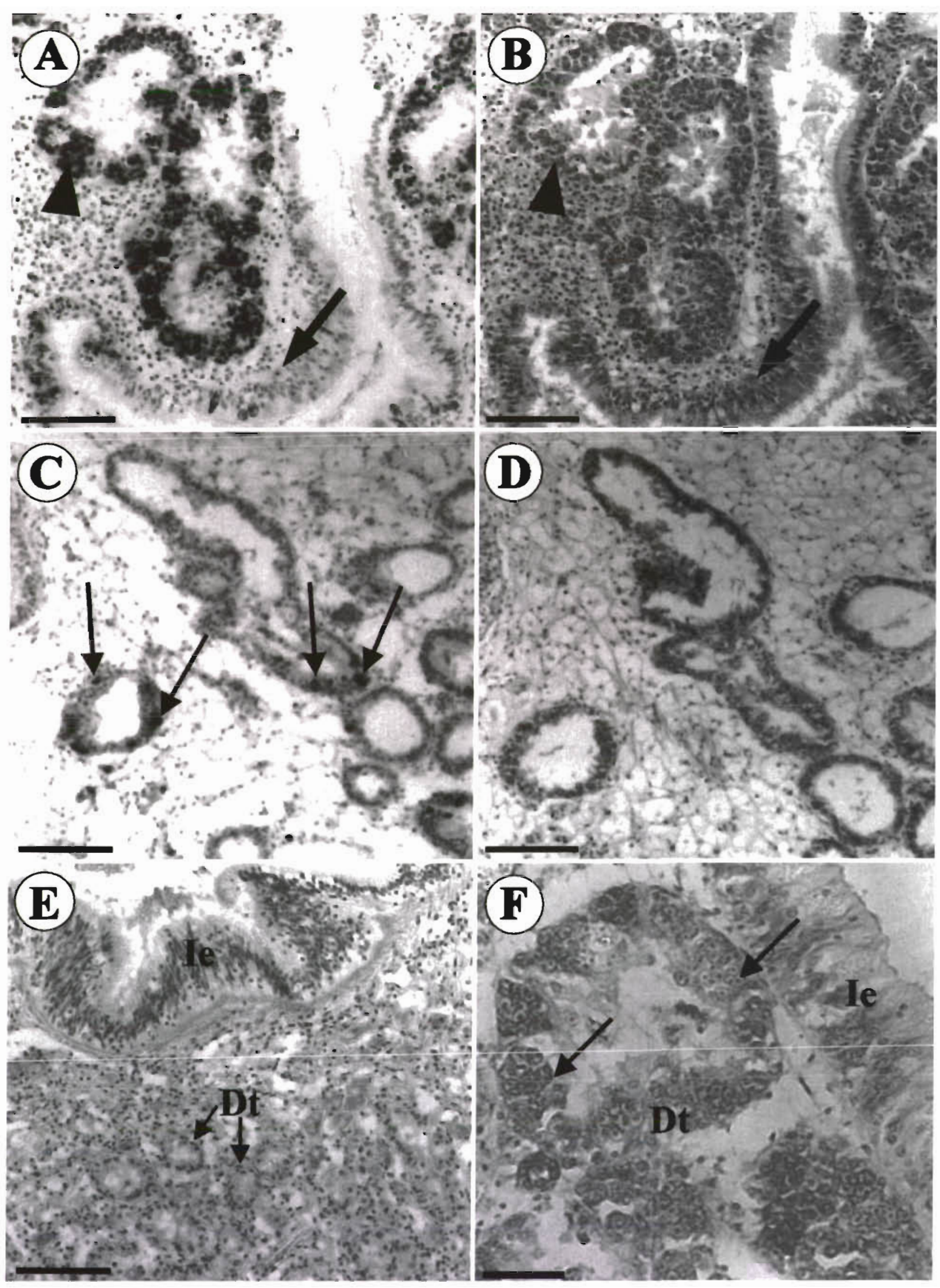


Fig. 6. Detection of Marteilia sydneyi DNA in tissue sections of the digestive gland of infected Saccostrea commercialis by in situ hybridisation with adjacent sections stained in $H \& E$ (A-D). Negative controls for in situ hybridisation (E-F). (A) In situ hybridisation with plasmodia (arrow) in the intestinal epithelia and spores within sporonts (1 of many sporont clusters indicated by the arrowhead) in the digestive tubules of a heavily infected oyster. (B) H\&E-stained section of the same individual as in (A). The same regions are indicated by arrows. (C) In situ hybridisation with presporulating stages (arrows) in the digestive tubules of a lightly infected oyster. (D) H\&E-stained section of the same individual as in (C). Scale bar A-D = 100 $\mu$ m. (E) Absence of reaction with in situ hybridisation using the DNA probe with uninfected oyster tissue. Scale bar $=120 \mu m_{;}(F)$ In situ hybridisation with the probe omitted with tissue from the same oyster as in (A) \& (B). Some of the many sporonts within sporangiosori are indicated by arrows. Scale bar $=40 \mu \mathrm{m}$. Dt: digestive tubule; le: intestinal epithelia

(Fig. 8B). Modification of the probe concentration for optimisation of the hybridisation procedure did not improve the likelihood of hybridisation in mature spores and concentrations of Proteinase $\mathrm{K}$ in excess of $10 \mu \mathrm{g}$ $\mathrm{ml}^{-1}$ compromised tissue morphology.

\section{DISCUSSION}

Assays developed for diagnosis of cryptic parasite stages in host tissue that are based on nucleic acid sequences must meet certain requirements to ensure reliable and accurate recognition of target DNA. Assays must prove to be: sensitive enough to detect low levels of infection and/or individual cells; unable to cross react with host tissue; and specific to the targeted

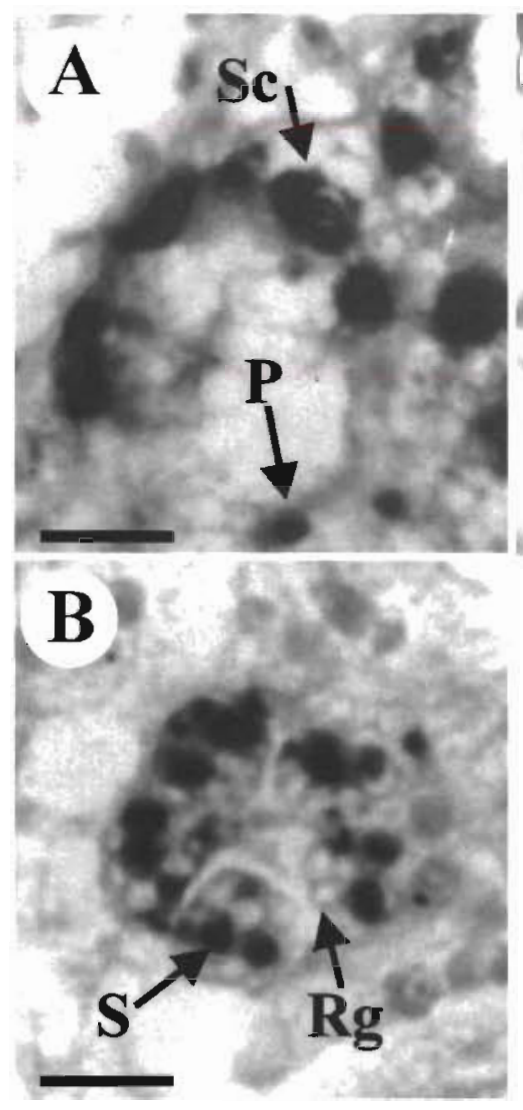

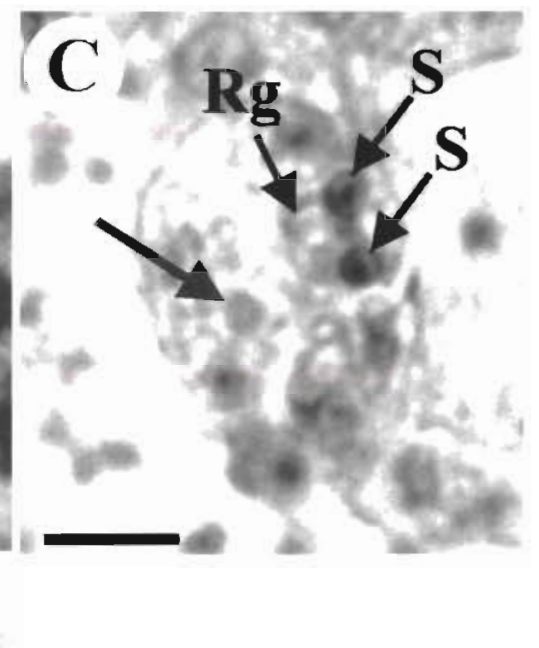

Fig. 7. Hybridisation of the DNA probe to various developmental stages of Marteilia sydneyi in tissue sections of infected Saccostrea commercialis. Detection within the oyster digestive tubules of: (A) presporulating stages; (B) immature spores within sporonts; (C) mature spores within sporonts. Unlabelled arrow in (C) indicates spore that has failed to hybridise. P: plasmodia; Rg: refringent granule; S: spore; Sc: secondary cell. Scale bar $=10 \mu \mathrm{m}$ pathogen among related species. Results of the present

The primer pair LEG1/PRO2 exhibited high detection sensitivity in PCR able to detect quantities of geomic Marteilia sydneyi DNA equivalent to 0.01 spooutlining the need to determine concentrations of host DNA, if any, that jeopardise the sensitivity of the $M$. sydneyi primer pair. While it is evident that PCR amplification of $M$. sydneyi is hindered following addition of increasing host DNA concentrations, detection of individual parasites is possible using this experimental approach with the addition of $<100 \mathrm{ng}$ of host genomic DNA in small reaction volumes. The PCR assay was validated further on environmental samples of QX-infected oysters using concentrations of template DNA previously determined to be suitable in $20 \mu \mathrm{l}$ reactions, demonstrating reliable detection of $M$. sydneyi DNA from amongst host DNA irrespective of intensity of infection.

The DIG-labelled DNA probe constructed using the primers LEG1 and $\mathrm{PRO} 2$ is a sensitive probe able to detect selectively Marteilia sydneyi DNA from that of Saccostrea commercialis. In dot blot hybridisation the probe recognised concentrations of $M$. sydneyi PCR-amplified DNA equivalent to $10 \mathrm{pg}$. In in situ hybridisation the DNA probe was able to localise individual parasites, of all developmental stages, within paraffinembedded oyster tissue. Absence of precipitates in uninfected oyster tissue sections confirms the specificity of the probe. 


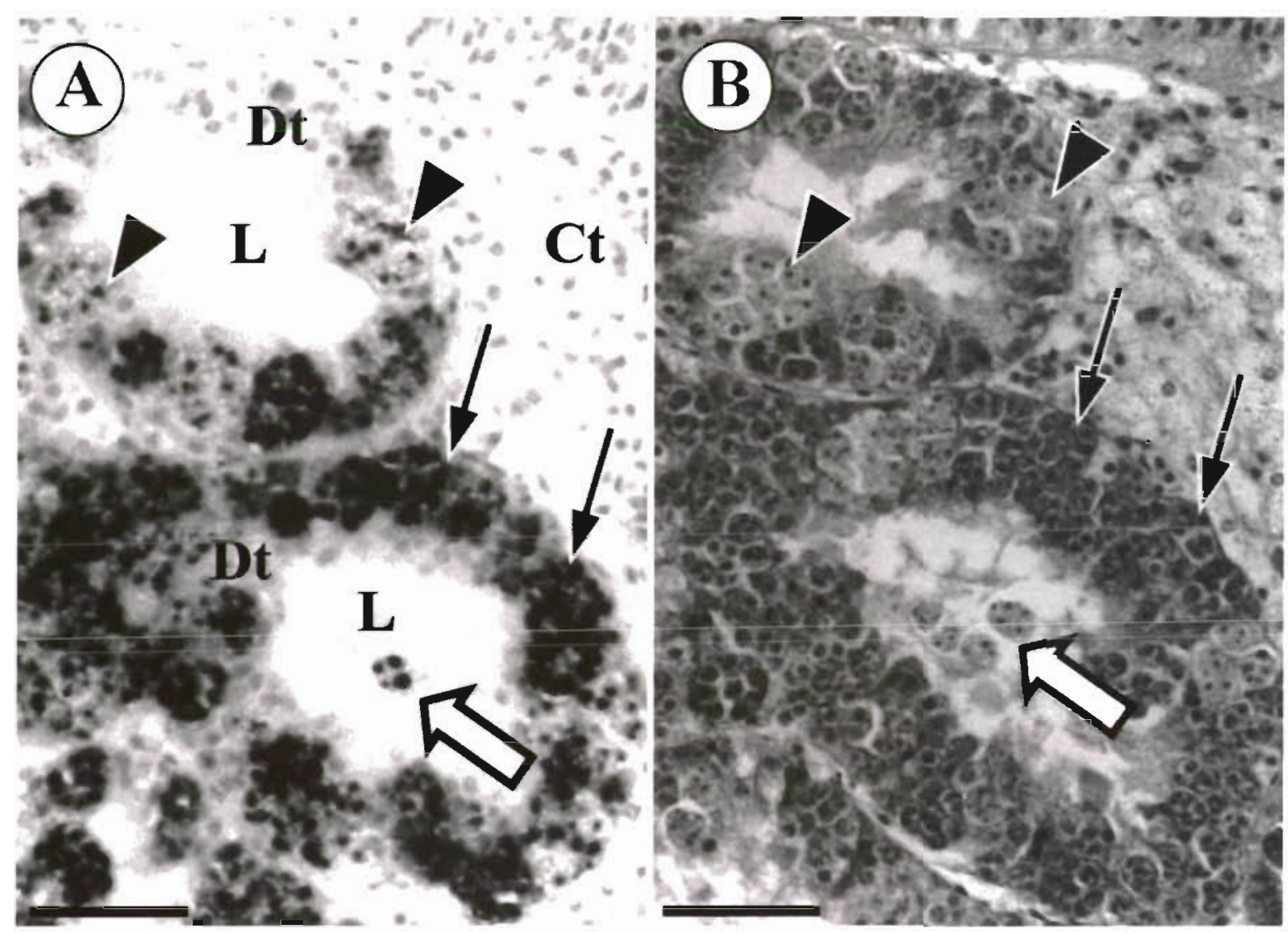

Fig. 8. Adjacent histological sections of Saccostrea commercialis infected with sporulating stages of Marteilia sydneyi. (A) In situ hybridisation; (B) H\&E stain. Mature sporonts shed into the lumen of the digestive tubules are indicated by the white block arrow Some of the many groups of mature sporonts within the digestive tubule walls are indicted by arrowheads. Groups of immature sporonts are depicted by arrows. Ct: connective tissue; Dt: digestive tubule; L: lumen. Scale bar $=50 \mu \mathrm{m}$

The variable signal intensity and inconsistent detection of mature spores within the oyster digestive tubules introduce some concerns regarding the reliability of the in situ hybridisation procedure for use in life cycle investigations. Mature spores are shed from the oyster host coupled in intact sporonts (Roubal et al. 1989) and presumably represent the stage infective to the intermediate host. Personal observations revealed that approximately $80 \%$ of mature spores, classified according to the size of refringent granules in the extraspore cytoplasm (Roubal et al. 1989), were amenable to hybridisation, alleviating some anxiety. Furthermore, spores within sporonts observed within the lumen of the digestive tubules and intestine manifest strong and consistent hybridisation signals. Stokes \& Burreson (1995) and Stokes et al. (1995) reported poor hybridisation of mature spores of 2 haplosporidian species, Haplosporidium nelsoni and Minchinia teredinis, and attributed this to the inability of either (or both) the probe or anti digoxygenin antibody to penetrate the thick spore wall. Impermeability of the spore wall in Marteilia spp., described as a 'thin envelope' (Desportes
1984) which does not variegate as the spore matures (Perkins \& Wolf 1976), is an unlikely explanation for differences in probe and antibody penetration in immature and mature spores in this study. Concentric myelin whorls, composed of degraded extraspore cytoplasm, progressively enclose the spore as it matures within the sporont (Perkins \& Wolf 1976); however, given that fixatives and embedding agents easily penetrate mature spores of $M$. sydneyi for ultrastructural study and are excluded in preparations of mature spores of Haplosporidia (Perkins 1990), the membranes should not compromise probe or antihody penetration.

Reduced signal intensity in mature spores, localised within the inner sporoplasms, may be directly related to the proportion of target DNA available. The characteristic cell-within-a-cell development of the Paramyxea is also associated with successive degeneration of superseded cells (Desportes 1984, Perkins 1988, Desportes \& Perkins 1990). Reduction of the outersporal cell to a thin cytoplasmic layer occurs during spore maturation of Paramyxa paradoxa, and in ma- 
ture spores of Marteilia sydneyi, absence of distinct ribosomes, lysis of plasmalemma and electronlucent appearance of ground cytoplasm (Perkins 1991) may explain lack of hybridisation signal in the outermost sporoplasm of mature spores. Sporonts shed from the oyster would represent the most mature spore stages, yet their detection was reliable, suggesting that some mature spores in tissue may have an inactive phase or are no longer viable. The combined use of viability stains and rRNA probes have been used to differentiate viable, inactive and dead cells of bacteria in situ (Williams et al. 1998) and may shed some light on this phenomenon.

The specificity of the LEG1/PRO2 primer pair and DIG-labelled DNA probe is yet to be tested on other Paramyxea species. The paramyxean Marteilioides branchialis infects the gills of Saccostrea commercialis and is found in QX endemic areas (Anderson \& Lester 1992). The likelihood of cross-reaction with this species, or other as yet undiscovered species, must be assessed. Given that the interspecific variability in the nucleotide sequence of internal transcribed spacer regions have allowed discrimination between congeneric species (Adlard et al. 1993), probes designed within the given gene sequence may prove to be species specific to Marteilia sydneyi.

The combined use of the PCR and in situ hybridisation tests developed and optimised in this study should provide a valuable research tool for the detection and localisation of Marteilia sydneyi life cycle stages in potential alternate hosts. While the high detection sensitivity of the PCR test will allow rapid screening of large numbers of potential alternative hosts for the presence of parasite DNA, it does not identify the infective stages themselves. In situ hybridisation conducted on paraffin sections will determine the locality of the parasite within the host and allow subsequent morphological characterisation.

Acknowledgements. We thank Dr Jess Morgan, University of Queensland, for her constructive suggestions and for providing assistance with PCR reactions. This research was supported by the University of Queensland Enabling Grant [009G98\} to Professor Robert Lester and R.D.A.

\section{LITERATURE CITED}

Adlard RD, Ernst I (1995) Extended range of the oyster pathogen Marteilia sydneyi. Bull Eur Assoc Fish Pathol 15 $119-121$

Adlard RD, Lester RJG (1995) Development of a diagnostic test for Mikrocytos roughleyi, the aetiological agent of winter mortality of the commercial rock oyster, Saccostrea commercialis. J Fish Dis 18:609-614

Adlard RD, Barker SC, Blair D, Cribb TH (1993) Comparison of the second transcribed spacer (ribosomal DNA) from populations and species of Fasciolidae (Digenea). Int $J$ Parasitol 23:423-425
Anderson TJ, Lester RJG (1992) Sporulation of Marteilioides branchialis $\mathrm{n}$. $\mathrm{sp}$. (Paramyxea) in the Sydney rock oyster. Saccostrea conmercialis: an electron microscope study. J Protozool 39:502-508

Anderson TJ, Adlard RD, Lester RJG (1995) Molecular diagnosis of Marteilia sydneyi (Paramyxea) in Sydney rock oysters, Saccostrea commercialis (Angas). J Fish Dis 18: $507-510$

Cabot EL, Beckenbach AT (1989) Simultaneous editing of multiple nucleic acid and protein sequences with ESEE. Comput Appl Biosci 5:233-234

Chang PS, Lo CF, Wang YC, Kou GH (1996) Identification of white spot syndrome associated baculovirus (WSBV) target organs in the shrimp Penaeus monodon by in situ hybridization. Dis Aquat Org 27:131-139

Desportes I (1984) The Paramyxea Levine 1979: an original example of evolution towards multicellularity. Origins Life 13:343-352

Desportes I, Perkins FO (1990) Phylum Paramyxea. In: Margulis L, Corliss JO, Melkonian M. Chapman DJ (eds) Handbook of Protoctista. Jones and Bartlett Publishers Boston, p 30-35

Diggles B, Adlard RD (1995) Taxonomic affinities of Cryptocaryon irritans and Ichthyophthirius multifilis inferred from ribosomal RNA sequence data. Dis Aquat Org 22 : $39-43$

Durand S, Lightner DV, Nunan LM, Redman RM, Mari J, Bonami JR (1996) Application of gene probes as diagnostic tools for white spot baculovirus (WSBV) of penaeid shrimp. Dis Aquat Org 27:59-66

Fong D, Chan MMY, Rodriguez R, Chen CC, Liang Y, Littlewood DTJ, Ford SE (1993) Small subunit ribosomal RNA gene sequence of the parasitic protozoan Haplosporidian nelsoni provides a molecular probe for the oyster MSX disease. Mol Biochem Parasitol 62:139-142

Lane JE, Olivares-Villagomez D, Vnencak-Jones CL, MCCurley TL, Carter CE (1997) Detection of Trypanosoma cruzi with the polymerase chain reaction and in situ hybridization in infected murine cardiac tissue. Am J Trop Med Hyg 56:588-595

Lester RJG (1986) Field and laboratory observations on the oyster parasite Marteilia sydneyi. In: Cremin M, Dobson C, Moorhouse DE (eds) Parasite lives. University of Queensland Press, Brisbane, p 33-40

Li W, Graur D (1991) Fundamentals of molecular evolution. Sinauer Associates Inc, Sunderland, MA, p 70-75

Lo CF, Ho CH, Chen CH, Liu KF, Chiu YL, Yeh PY, Peng SE, Hsu HC, Liu HC, Chang CF, Su MS, Wang CH, Kou GH (1997) Detection and tissue tropism of white spot syndrome baculovirus (WSBV) in captured brooders of Penaeus monodon with a special emphasis on reproductive organs. Dis Aquat Org 30:53-72

Mialhe E, Bachere E, Le Bec C, Grizel H (1985) Isolement et purification de Marteilia (Protozoa: Ascetospora) parasite de bivalves marins. CR Acad Sci (Ser III) 302:137-142

Perkins FO (1988) Parasite morphology, strategy, and evolution. Am Fish Soc Spec Publ 18:93-111

Perkins FO (1990) Phylum Haplosporidia. In: Margulis L, Corliss JO, Melkonian M, Chapman DJ (eds) Handbook of Protoctista. Jones and Bartlett Publishers, Boston, p 19-29

Perkins FO (1991) Sporozoa: Apicomplexa, Microsporidia, Haplosporidia, Paramyxea, Myxosporidia, and Actinosporidia. In: Harrison FW, Corlis JO (eds) Microscopic anatomy of invertebrates, Vol 1, Protozoa. Wiley-Liss, Brisbane, p 261-331

Perkins FO, Wolf PH (1976) Fine structure of Marteilia syd neyi sp. n.- Haplosporidian pathogen of Australian oys- 
ters. J Parasitol 62:528-538

Roubal FR, Lester RJG (1987) New test developed for QX parasite in oysters. Aust Fish 46:38

Roubal FR, Masel J, Lester RJG (1989) Studies on Marteilla sydneyi, agent of $\mathrm{QX}$ disease in the Sydney rock oyster, Saccostrea commercialis, with implications for its life cycle. Aust J Mar Freshw Res 40:155-167

Sambrook J, Fritsch EF, Maniatis T (1989) Molecular cloning a laboratory manual, 2nd edn. Cold Spring Harbour Laboratory Press, Cold Spring Harbour, NY

Stokes NA, Burreson EM (1995) A sensitive and specific DNA probe for the oyster pathogen Haplosporidium nelsoni. J Eukaryot Microbiol 42:350-357

Stokes NA, Siddall ME, Burreson EM (1995) Small subunit ribosomal RNA gene sequence of Minchinia teredinis (Haplosporidia: Haplosporidiidae) and a specific DNA

Editorial responsibility: Larry Vaughan,

Portsmouth, New Hampshire, USA probe and PCR primers for its detection. J Invertebr Pathol $65: 300-308$

Wang CS, Tsai YJ, Kou GH, Chen SN (1997) Detection of white spot disease virus in wild-caught greasy back shrimp, Metapenaeus ensis (de Haan) in Taiwan. Fish Pathol 32:35-41

Wesche SJ, Adlard RD, Lester RJG (1999) Survival of spores of the oyster pathogen Marteilia sydneyi (Protozoa, Paramyxea) as assessed using flurogenic dyes. Dis Aquat Org 36:221-226

Williams SC, Hong Y, Danavall DCA, Howard-Jones $\mathrm{MH}$, Gibson D, Frischer ME, Verity PG (1998) Distinguishing between living and non living bacteria: evaluation of the vital stain propidium iodide and its combined use with molecular probes in aquatic samples. J Microbiol Methods $32: 225-236$

Submitted: January 10, 1999; Accepted: October 24, 1999 Proofs received from author(s): February 15, 2000 